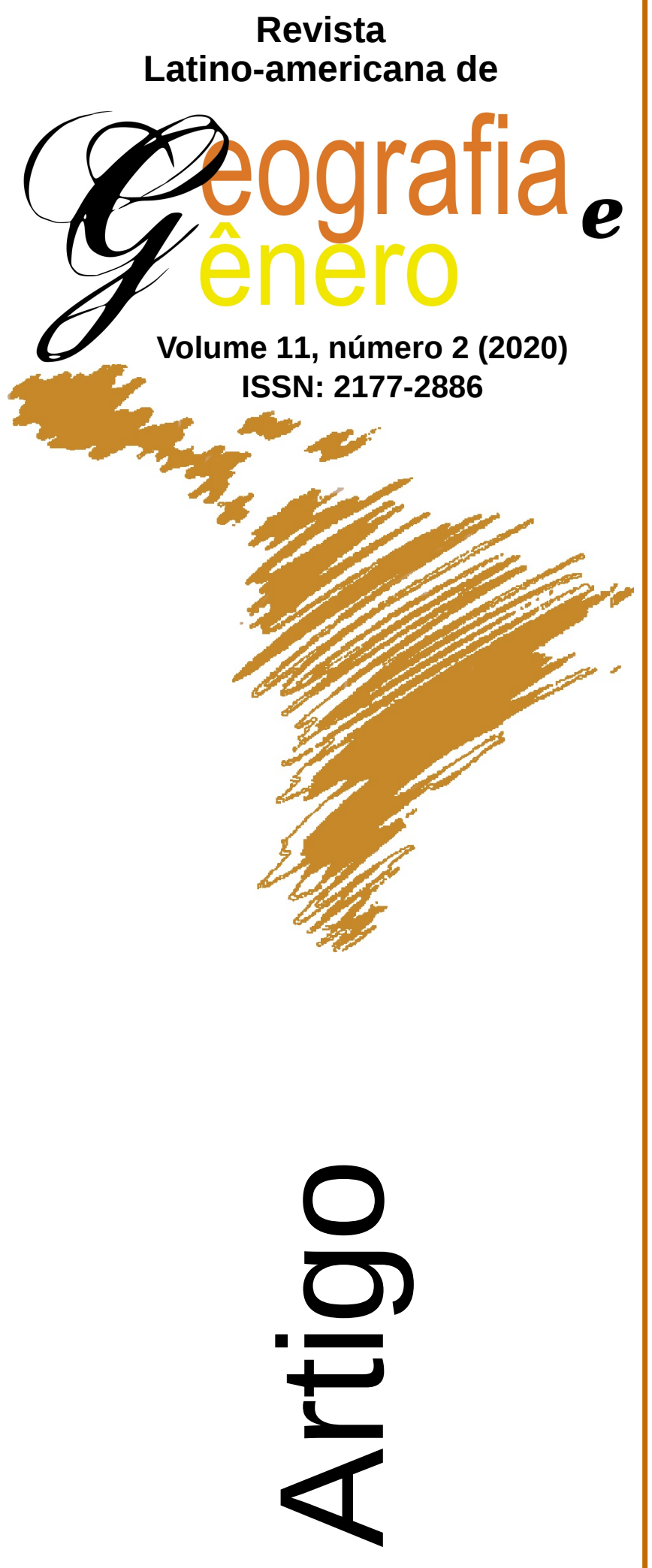

\title{
Não é Não! Entre Redes e Ruas: Conflitualidade entre Cultura da Violência e Corpos de Mulheres
}

¡No es No! Entre las Redes y las Calles: Conflictos entre la Cultura de Violencia y Cuerpos de Mujer

No is No! Between Networks and Streets: Conflictuality between Culture of Violence and Women's Bodies

\author{
Maria Simone Vione Schwengber \\ Universidade Regional do Noroeste do Estado \\ do Rio Grande do Sul - Brasil \\ simone@unijui.edu.br

\section{Daniela Zeni Dreher} \\ Universidade Regional do Noroeste do Estado \\ do Rio Grande do Sul - Brasil \\ daniela.dreher@unijui.edu.br

\section{Naira Leticia Giongo Mendes Pinheiro Universidade Regional do Noroeste do Estado do Rio Grande do Sul - Brasil nairaleticiagmendespinheiro@gmail.com}

Como citar este artigo:

SCHWENGBER, Maria Simone Vione; DREHER, Daniela Zeni; PINHEIRO, Naira Leticia Giongo Mendes. Não é Não! Entre Redes e Ruas: Conflitualidade entre Cultura da Violência e Corpos de Mulheres. Revista Latino Americana de Geografia e Gênero, v. 11, n. 2, p. 130-145, 2020. ISSN 2177-2886.

Disponível em:

http://www.revistas2.uepg.br/index.php/rlagg 


\title{
Não é Não! Entre Redes e Ruas: Conflitualidade entre Cultura da Violência e Corpos de Mulheres
}

\author{
¡No es No! Entre las Redes y las Calles: Conflictos entre la Cultura de \\ Violencia y Cuerpos de Mujer
}

\author{
No is No! Between Networks and Streets: Conflictuality between Culture of \\ Violence and Women's Bodies
}

\section{Resumo}

Este artigo articula discussões sobre as repercussões da campanha Não é Não. Desse modo, lançando as seguintes questões: De que modo a campanha Não é Não responde e/ou contesta as violências corporais sobre os corpos das mulheres? O corpus de análise é constituído por recortes de dizeres enunciativos e imagens da campanha Não é Não (2017-2020), postadas em redes sociais digitais. O percurso teórico-metodológico de análise é inspirado na perspectiva foucaultiana. Destacamos que a campanha Não é Não desloca o silêncio das violências à publicização e à verbalização, nas ruas e nas redes, movimento que opera com a resistência dos corpos de mulheres. Põem-se em prática as novas formas de conflitualidade política e articulam corpos e espaços urbanos e mídias digitais na esfera pública. Concluímos que a campanha se move no duplo sentido: como um movimento dos corpos e como um movimento político.

Palavras-Chave: Corpo; Cultura; Gênero; Violência Simbólica.

\section{Resumen}

Este artículo articula discusiones sobre las repercusiones de la campaña "Não é Não". Por ello, planteamos las interrogantes: ¿Cómo la campaña "Não é Não" responde y/o encara la cuestión de la violencia corporal en el cuerpo de las mujeres? El corpus de análisis está constituido por recortes de diversos enunciados, narrativas e imágenes de la campaña "Não é Não" (2017-2020), publicados en las redes sociales digitales. El proceso de análisis teóricometodológico se inspira en la perspectiva foucaultiana. Destacamos que la campaña "Não é Não" traslada el silencio de la violencia a la publicidad y a la verbalización, tanto en las calles como en las redes, de un movimiento que opera con la resistencia de los cuerpos de las mujeres. Nuevas formas de conflicto político se ponen en práctica y articulan cuerpos, espacios urbanos y medios digitales en la esfera pública. Concluimos que la campaña se desarrolla en dos direcciones: como un movimiento de los cuerpos y como un movimiento político.

Palabras-Clave: Cuerpo; Cultura; Género; Violencia Simbólica.

\section{Abstract}

This article articulates discussions about the repercussions of the Não é Não (No is No) campaign. To achieve the aim of this study the following question was asked: How does the campaign Não é Não respond to and / or contest bodily violence against women's bodies? The analysis corpus consists of clippings of enunciative sayings and images from the Não é Não (2017-2020) campaign, posted on digital social networks. The theoretical-methodological 


\section{Corpos de Mulheres}

background includes the Foucaultian perspective. We emphasize that the Não é Não campaign provokes a shift from the violence silence to publicity and verbalization, in the streets and on networks, in a movement that operates with the resistance of women's bodies. New forms of political conflict are put into practice and articulate bodies and urban spaces and digital media in the public sphere. We concluded that the campaign unfolds in two directions: as a movement of bodies and as a political movement.

Keywords: Body; Culture; Gender; Symbolic Violence.

\section{As Marias não estão Dispostas a Silenciar as Violências Corporais}

$\underline{E} \underline{\text { agora }}$ Maria? E agora?

(Thais Candido Stutz Gomes, 2015, p. 12)

Vão dizer que a tua luta não tem sentido.

Te chamar de louca.

Mas ele se nega a lavar a louça.

Que o machismo já foi superado.

Mas você recebe elogio na fila do mercado.

Você tem medo de andar sozinha.

"Gostosa, e essa sainha?"

Se quer ser respeitada, se dê o respeito!

Nem louca, nem bruxa, nem santa, nem puta.

Você é mulher e é sua essa luta.

Tantas vitoriosas, talentosas, virtuosas.

Jogue a caixa fora e grite para quem insiste em produzi-la, reproduzi-la, distribui-la.

Somos partidárias de uma corrente revolucionária.

Essa radical ideia ainda vai tomar o mundo, tenho fé: $\underline{A} \underline{\text { Maria não }} \underline{\text { é menor }}$ que o $\underline{\text { José. }}$

A poesia de Gomes (2015), apresentada na epígrafe, destaca a possibilidade, cada vez menor, da Maria ou das Marias se calarem, ou ainda, de silenciarem suas vozes. Algumas Marias têm dito que "não são menores que o José." Percebe-se de um modo geral que um grupo de mulheres (ou de Marias) não está mais disposto aos silêncios e silenciamentos, seja de seus corpos, de seus discursos ou de seus posicionamentos, que no conjunto dizem das condições de gênero. Assim, algumas mulheres têm produzido alguns movimentos de caráter agregador, que coalizam em algumas lutas de contestação, de resistências, justamente no que exigem: respeito e/ou dignidade aos seus corpos. "Vivemos tempos temerosos, ${ }^{1}$ mas é inegável que nos mesmos instantes presenciamos uns tempos de vozes insurgentes" ${ }^{2}$ (HOOKS, 2013, p. 41), tempo de lutas daqueles e daquelas que ao longo da história têm tido seus corpos objetificados, assediados, violados. Dessa forma, o presente artigo busca analisar as relações de contestação das violências corporais no território brasileiro e suas reverberações a partir da campanha Não é Não (que

1 Sugerimos o documentário Gênero sob ataque, que aborda a ofensiva de grupos religiosos e políticos na América Latina.

2 Dessa forma, lutas insurgentes são aquelas cujas práticas e ações são guiadas por uma "ideia radicalmente democrática de liberdade e justiça para todos" (HOOKS, 2013, p. 41). 
Destacamos o quanto há um marcador comum presente nessas violências, que geralmente têm como elemento-chave 'os corpos'. Violências as quais são marcadas nos e pelos corpos. Há uma crença de propriedade masculina dos corpos das mulheres, uma certa objetificação dos corpos das mulheres. Assim, os corpos, semelhantes a qualquer tipo de objeto, podem ser usados, mortos, descartados. Por outro lado, também observamos um paradoxo, que penaliza as meninas e as mulheres que assumem a vivência da sua corporeidade e sexualidade, e que continuam a sofrer pressão da promoção do designado 'bom' comportamento ou ainda da 'bem comportada'. Ao mesmo tempo em que há repressão e o silenciamento dos corpos e da sexualidade, no quadro do que geralmente se exige das meninas e das mulheres ao censurar, julgar os direitos corporais, posicionando-as em quase subcidadania sexual da recatada (MACEDO, 2012).

Neste contexto paradoxal, o Brasil contemporâneo, como território das 


\begin{abstract}
campanha Não é Não (o que detalharemos na próxima seção) conduzida por um grupo de mulheres brasileiras.

A campanha Não é Não emerge no Brasil como resposta à violência aos corpos das mulheres. Optamos por estudá-la porque há parcos registros acadêmicos de campanhas no Brasil, que traduzem movimentos reivindicatórios que buscam educar, de modo particular os homens, pelo respeito aos corpos das mulheres, para marcar as diferenças entre uma paquera e um assédio, assim como desnaturalizar os próprios assédios. Muitas conquistas e avanços civilizatórios foram vividos, especialmente a partir da segunda metade do século XX no Brasil, materializando-se em legislações, em políticas públicas, em diretrizes educacionais. Mas parece que quando se trata de valores arraigados culturalmente, é necessário muito mais esforços para mudar padrões de comportamentos. Por essas razões entendemos como fundamental examinar uma campanha como essa.

O recorte de matrizes de análise nesse artigo vai na direção do que Butler (2018) postula. Para ela, as reuniões em assembleias corporificadas, presenciais ou não, implicam na ressignificação política dos corpos nos espaços públicos. Nesse sentido, os corpos aparecem, então, como expressão política transitória, reúnem-se em assembleias, em manifestações públicas e fazem as reivindicações. Diante da condição de precarização, da ausência de reconhecimento, um grupo de mulheres rejeita as dores das violências que sofre. Reunidas, lutam performativamente para que essas violências se politizem.
\end{abstract}

\title{
Campanha 'Não é Não'
}

Com a campanha Não é Não podemos pensar o ativismo feminino a partir do hibridismo online/offline ou, ainda, pela conexão entre grupo de mulheres, as redes sociais digitais da internet e os atos de ruas-território. Para Castells (2013, p. 173-174), a vida cotidiana contemporânea tem sido movida entre o online e o offline, visto que não são dimensões apartadas. Ele afirma que a nossa sociedade não é "puramente virtual”, há uma conexão íntima entre as redes virtuais e as redes na vida social. Para Castells, é "nesse mundo que os movimentos sociais em rede vieram à luz, numa transição - natural, para muitos indivíduos - do compartilhamento de sua sociabilidade para o compartilhamento de sua indignação, de sua esperança e de sua luta" (CASTELLS, 2013, p. 173-174).

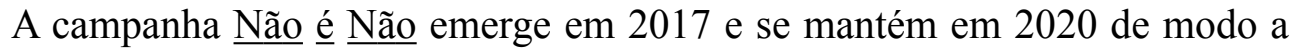
permitir pensarmos que se nacionalizou. Emergiu como uma iniciativa de grupo/bloco de carnaval de mulheres no Rio de Janeiro, em reação a casos de assédios que ocorriam na época. Depois de ter sido publicizado, várias histórias similares rapidamente começaram a surgir, foram compartilhadas, ganharam espaços, nos blocos oficiais, no sambódromo, nas praias, shows e em diferentes festas tradicionais brasileiras. Depois do carnaval de 2017, entendeu-se "que a única possibilidade do Não é Não continuar crescendo era dar a mão para mais mulheres, formar uma rede, ainda mais forte, diversa, articulada no coletivo". ${ }^{7}$ A campanha é reforçada por coordenadorias de Políticas para as Mulheres, secretarias estaduais e municipais de Direitos Humanos. Também foram identificados e mapeados outros coletivos e 
Para Courtine (2003, p. 22), “a mensagem política não é mais unicamente linguística, mas uma colagem de imagens e uma performatividade do discurso que deixou de ser prioritariamente verbal". Ao tratar dos limiares do verbal com a imagem, Foucault declara que "a relação da linguagem com a imagem é uma relação infinita. Não que a palavra seja imperfeita e esteja num déficit que em vão se esforçaria por recuperar" (FOUCAULT, 2013, p. 63).

As imagens implícitas funcionam como pistas, favorecendo a compreensão das associações de ordem do discurso. Há uma ligação entre o texto verbal e o não verbal, que captam o olhar do enunciatário e facilitam a correlação dos argumentos, explicitada na campanha como uma simbiose. Buscaremos não as desvincular no exercício analítico, reiterar que a própria escolha de uma

7 Disponível em: https://tinyurl.com/y5s6aae7

Maria Simone Vione Schwengber, Daniela Zeni Dreher, Naira Leticia Giongo Mendes Pinheiro 


\section{Corpos de Mulheres}

imagem em detrimento de outra é indicativo das posições mantidas e reforçam os lugares ocupados e sustentados. Por ora, acreditamos que as noções aqui apresentadas são suficientes para dar sustentação à análise que propomos empreender, a qual se desenrolará a seguir. Feitas essas considerações, nosso esforço na próxima seção centra-se em apresentar o movimento investigativo de análise.

\section{Do Silêncio à Verbalização dos Corpos}

Apresentamos a seguir, na Figura 1, uma imagem que apresenta como é o funcionamento da campanha Não é $\underline{\text { Não. }}$

Figura 1 - Campanha Não é Não na aplicação de tatuagens
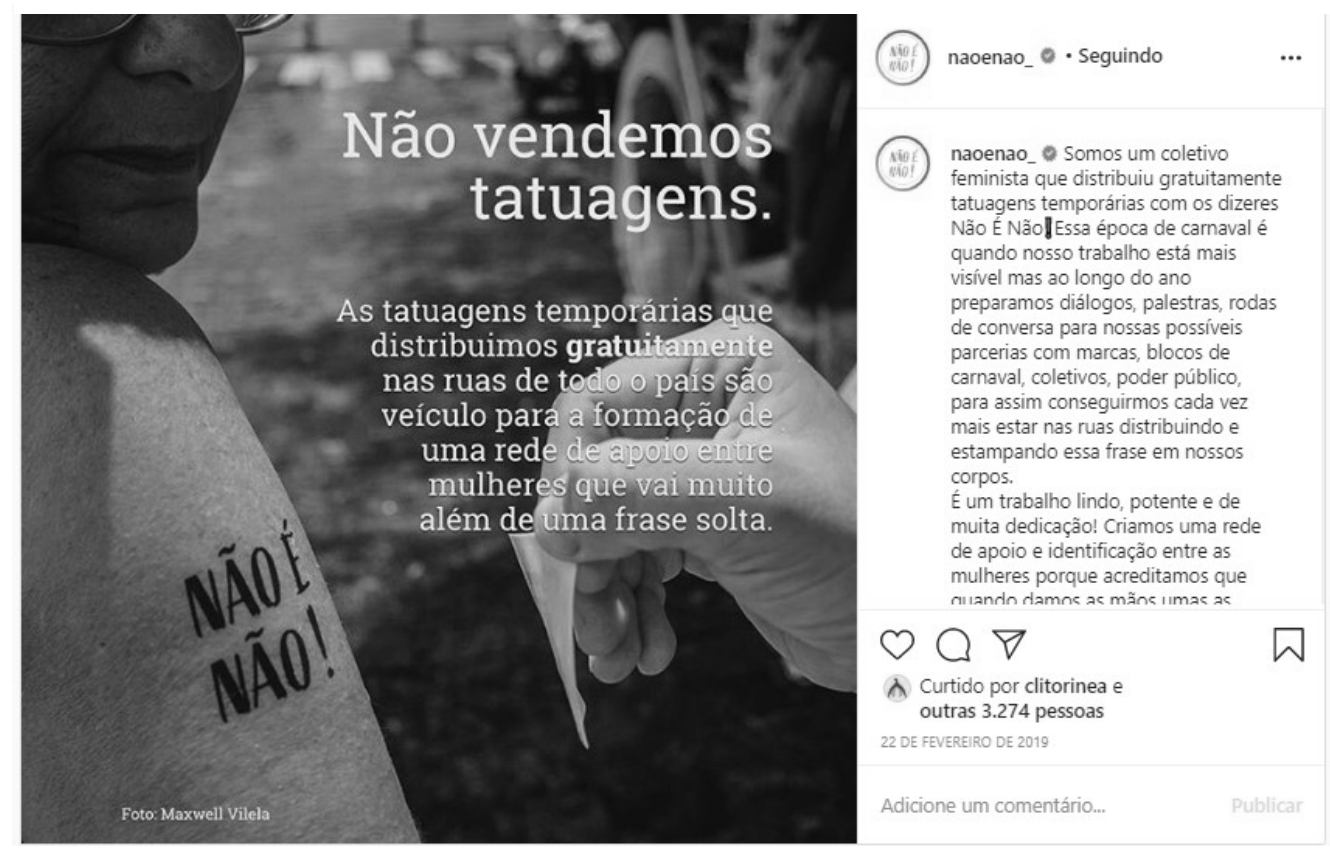

Fonte: Não é não (2019a).

Como se vê, a campanha 'opera' a partir da escrita na pele/corpo, realçada por letras maiúsculas (como se estivesse falando alto/sério), chamando a atenção para a máxima 'NÃO É NÃO!'. Observa-se que a campanha Não é Não opera com a responsividade de um corpo, situando-a na órbita de uma agência política, seu "discurso carrega o traço mnêmico do corpo na força que exercita" (BUTLER, 2015, p. 159). A campanha transforma os corpos na própria mensagem do protesto.

A campanha Não é Não transita entre o corpo e a linguagem. E nesse 'entre' há reivindicações de um direito, que articula num plano "inteligível e dizível" (FOUCAULT, 2014), na esperança de conquistá-lo. Silenciar, além de reafirmar a violência sofrida, faz com que tais dimensões culturalmente não sejam tratadas. "O silêncio é mantenedor da violência" (RIBEIRO, 2013, p. 12). Para Ribeiro, “[...] a objetificação, a inferiorização, a exotização exacerbada dos corpos das mulheres, construída historicamente desde a experiência colonial brasileira começa a ser combatida. A naturalização das violências corporais precisa ser enfrentada" (RIBEIRO, 2013, online).

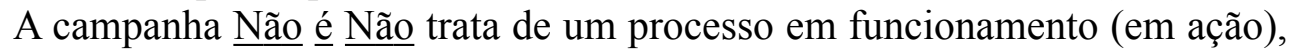
diz de um sair reflexivamente do silêncio para a verbalização. Neste percurso,

Maria Simone Vione Schwengber, Daniela Zeni Dreher, Naira Leticia Giongo Mendes Pinheiro 
Destacamos que a campanha Não é Não opera com a resistência dos próprios corpos das mulheres. Os corpos aparecem entre si (BUTLER, 2018), do ponto de vista de ativistas, que põem em prática as novas formas de conflitualidade política e articulam os corpos, os espaços urbanos e as redes digitais na esfera pública. A performatividade política da campanha passa pelos corpos, movendo a campanha num duplo sentido, "como movimento dos corpos e como um movimento político" (BUTLER, 2018, p. 188) e configurase assim como as novas ecologias singularizadas pelo conflito de quem fala, como destaca Di Felice (2013), ao mesmo tempo que operam uma insurgência pela via performativa (BUTLER, 2015; 2018) - o uso dos corpos e da linguagem, justamente para reivindicar o direito.

A campanha destaca a resistência, principalmente no que tange aos corpos em exposição que deslocam as violências. E assim produzem uma performatividade no espaço-território público, como destaca Butler (2015). Esse grupo de mulheres, ao encarnar essa pauta através da campanha, submete suas reivindicações entre redes e ruas. "Saem do sofá" (VALENZUELA, 2014) e performam a partir da superfície de seus próprios corpos, visto que geralmente tais manifestações perturbam a hegemonia das estruturas dominantes. Essas manifestações articulam atos performativos que visibilizam as precariedades que incide sobre esses corpos.

A crítica que se produz no sentido da contestação da condição precária dos corpos das mulheres busca ampliar as reivindicações sociais e políticas sobre os direitos de proteção a partir de uma 'nova' ontologia corporal (BUTLER, 2018). É dessas posições dos corpos em público que se produz as posições dignificadas das condições de gênero, em enunciados reflexivos - por meio de um eu político individual ao mesmo tempo acionado pelo nós político. Diferentes vozes projetam-se a partir do qual cada sujeito pode dizer em um coletivo que dá corpo às reivindicações por reconhecimento.

Para Butler e Athanasiou (2013), quando grupos se reúnem, performam demandas - aqui, no caso, pelo fim das condições de precariedade e despossessão (dispossession). Para as autoras (2013), a noção de dispossession requer ser compreendida em sentido de exposição à alteridade, de sujeitos em situação de precariedade que reclamam a inclusão em uma norma de vida vivível, ao mesmo tempo em que subvertem. Nesse ponto, recorremos a Babo (2017), para pensar sobre a dimensão da 'rua' quando ocupada por movimentos como esse:

A rua é o eixo aglutinador de todos os confrontos, de todos os fenómenos na cidade. [...] entendemos a rua como o palco dos conflitos, das irrupções colectivas, ideológicas, políticas na cidade. [...] É na rua que se exprime o conflito, o acto de pichagem, como acto performativo antiestético, de contestação/ apropriação. [...] A apropriação da rua na cidade contemporânea é de tal forma 
incontornável que constitui um questionamento urbano ao modelo das democracias representativas de modo a provocar, senão a sua falência, por certo a sua crise (BABO, 2017, p. 11).

Desse modo, esse grupo de mulheres brasileiras reivindica um direito público e legal - o direito contra a violência dos corpos - em locais públicos, produzindo outras políticas performativas.

\section{Não é Não: Alianças e Movimentações de Assembleias nas Ruas nos Territórios Brasileiros}

Nesta seção, nosso esforço analítico é o de destacarmos a capacidade de territorialização da campanha Não é Não no contexto brasileiro. Pensar a campanha conduz à ampliação das ações e se aproxima daquilo que Butler diz de uma "política das ruas" (BUTLER, 2018). Butler (2018, p. 17) nos ensina a pensar a tese "de que os protestos se expressam por meio de reuniões, de assembleias em espaços públicos, ancora-se na constatação de que os corpos são o objeto de manifestações que têm as próprias precariedades como impulso fundamental". Assim, a campanha Não é Não responde às condições de precariedades e de violências contra os corpos das mulheres. Precariedades, para Butler $(2018$, p. 23), não se confunde com uma posição apenas de passividade ou de exclusão. Mas também implica em uma posição de resistência, na medida em que expõe e encena uma resistência aos poderes instituídos, reconfigurando o direito de aparecer.

As assembleias, os encontros desses grupos da campanha, expõem que estão diante de condições compartilhadas de injustiça e exigem condições dignas para uma outra existência que seria uma alternativa ética e social da responsabilização do Outro, aquele que agride (BUTLER, 2018, p. 23). Tal pressuposto pode ser observado na Figura 2.

Figura 2 - Aplicação da tatuagem da Campanha Não é Não pelo Brasil afora
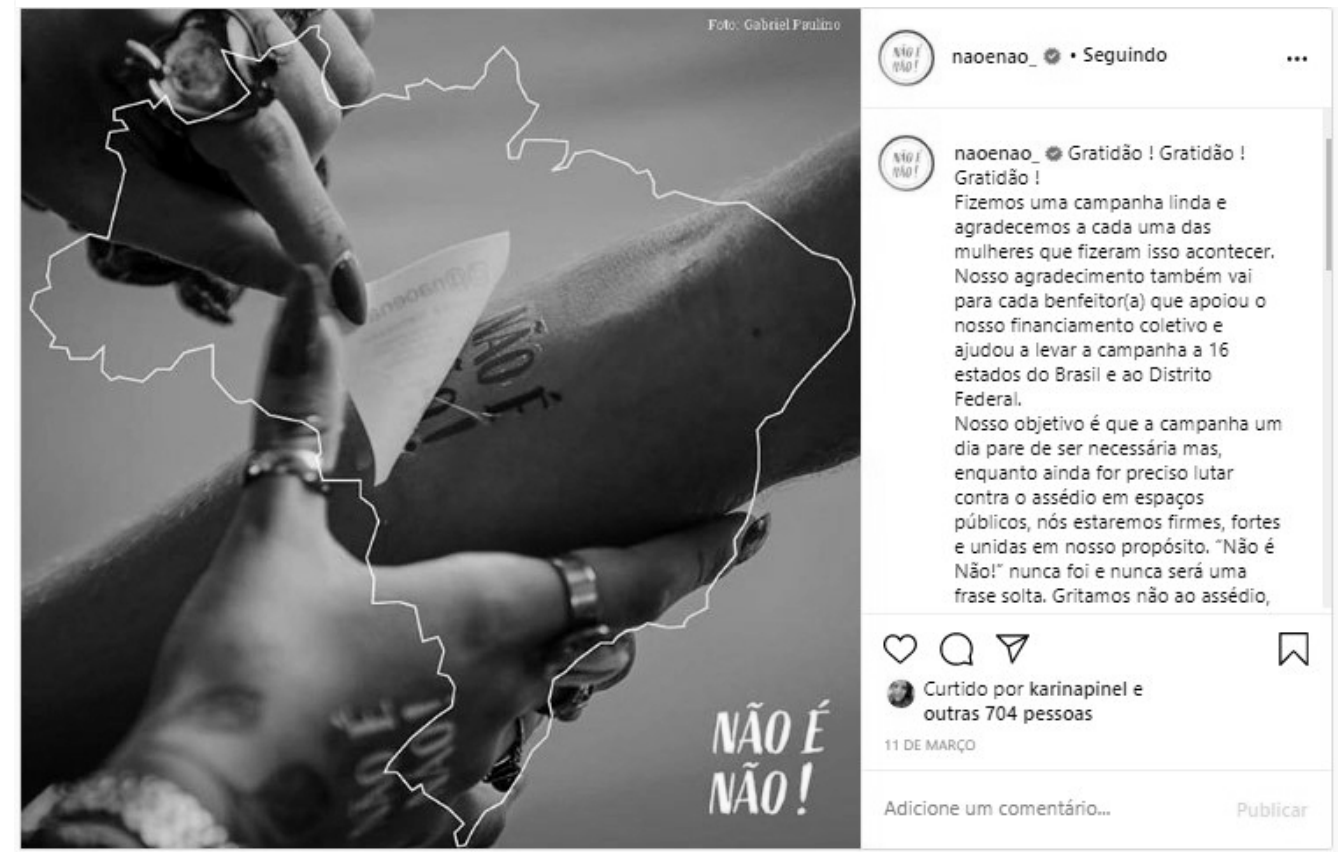

Fonte: Não é não (2020).

Maria Simone Vione Schwengber, Daniela Zeni Dreher, Naira Leticia Giongo Mendes Pinheiro 
O pressuposto aqui das mãos: uma não solta o braço da outra, na aplicação de tatuagens nos corpos, dá a ideia de uma 'política de coalizão' associada às individualidades e coletividades em "assembleias provisórias, tecendo resistências pelo direito de aparecer" (BUTLER, 2018, p. 40), de festejar juntas. A descrição da imagem, na Figura 2, dá conta da espalhabilidade da campanha, ao chegar a 16 estados e no Distrito Federal.

A espalhabilidade da campanha Não é Não se deu (e se dá) em diferentes estados e cidades brasileiras, em redes de sustentação, como podemos ver, em que o próprio corpo das mulheres em condições (precárias) de abjeto torna-se político. Observamos que esse movimento de espalhabilidade endossa uma educação pública de tal reivindicação, movimentada com recursos oriundos de financiamento coletivo, através de outras campanhas na internet.

A seguir, a Figura 3 ajuda a pensar a espalhabilidade da campanha em estados brasileiros, aqui representando o recorte do território de Minas Gerais.

Figura 3 - Mapa com nomes de mulheres
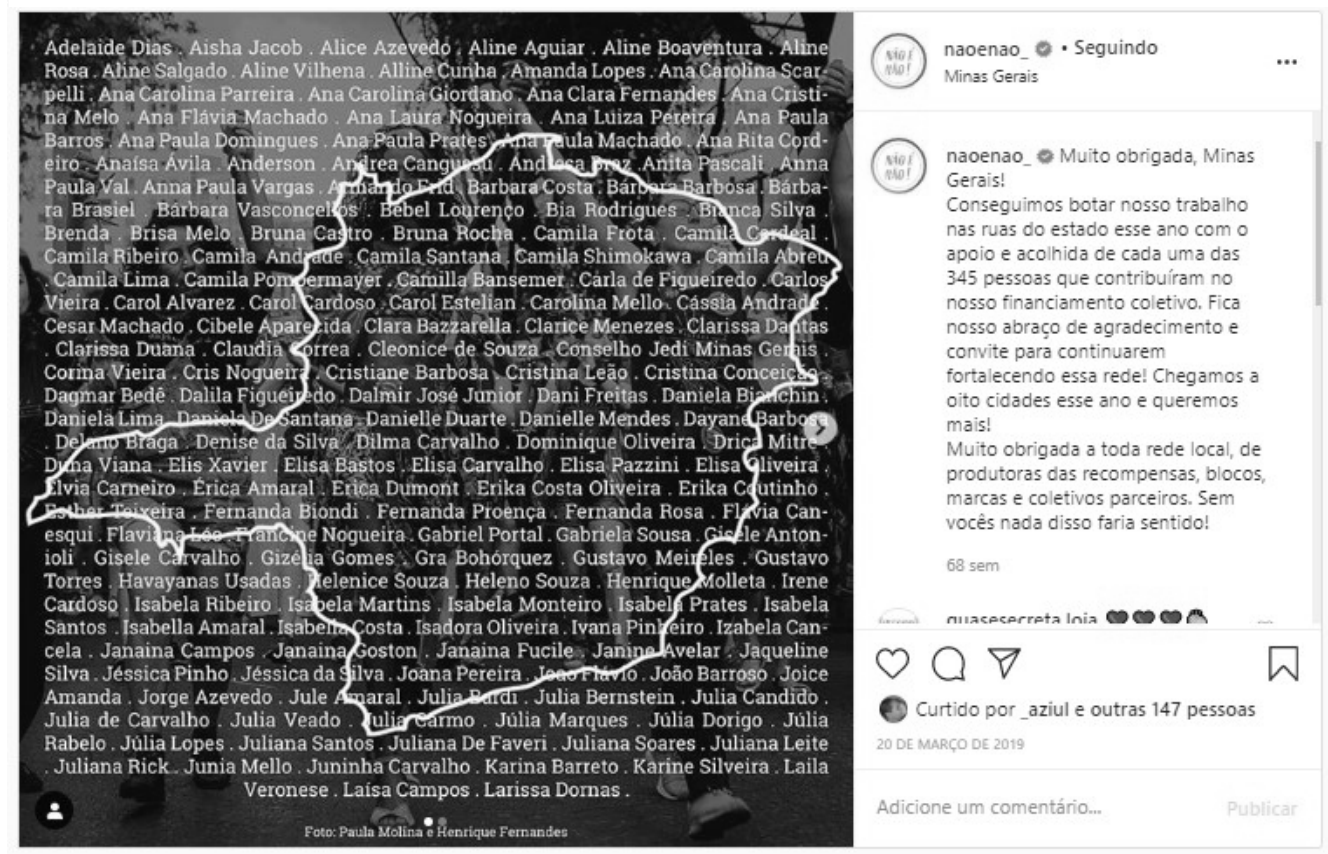

Fonte: Não é não (2019b).

Como se vê, a espalhabilidade territorial desta campanha é destacada no mapa, representando um estado do Brasil, com nomes e sobrenomes de diferentes mulheres, que inclusive saem (esparrama) para fora das fronteiras territoriais, o que contribui como enunciado discursivo, para mostrar que a campanha não tem limite, pois cresce, se espalha, se amplia. As imagens publicizadas nas redes oficiais da campanha Não é Não faz um agradecimento à aderência de diferentes grupos de mulheres em diferentes estados brasileiros e cidades, ao que parece ser um indicativo de que há em curso um novo sujeito político, as mulheres, que exigem o direito de proteção de seus corpos e buscam talvez a abertura de um espaço para colocar em evidência suas reivindicações, exigindo igualdade de tratamento de seus corpos.

Esses grupos se organizam (e organizaram) nos diferentes estados brasileiros por meio da composição de assembleias em espaços públicos, o que

Maria Simone Vione Schwengber, Daniela Zeni Dreher, Naira Leticia Giongo Mendes Pinheiro 
As condições de aparições da campanha incluem "as condições de infraestrutura para a encenação, bem como os meios tecnológicos para capturar e transmitir uma reunião, um encontro, nos campos visual e acústico" (BUTLER, 2018, p. 26). Os grupos de mulheres no Brasil, como as participantes da campanha, engendram em comunidade, essa que nasce da embriaguez comum das precariedades da condição corporal, das denúncias dos modos de como os corpos são tratados, assediados. Butler (2018) destaca a dependência de infraestrutura, e dentre essa as redes sociais, como fundamental para elaborar formas coletivas de abordar as condições precárias, por isso traz o binômio "redes e ruas".

Para Butler (2018, p. 17), "quando os corpos se juntam na rua, na praça ou em outras formas de espaço público (incluindo os virtuais), [como essa campanha possibilita,] eles estão exercitando um direito plural e performativo de aparecer". Um direito que afirma e instaura os corpos no campo político, o que busca um conjunto mais suportável de condições dignas, não mais afetadas pelas formas precárias pelas quais são submetidas (BUTLER, 2018).

Assim, consideramos a constituição de grupos e suas territorializações (no território brasileiro, por exemplo) como um exercício performativo, ainda que condicionado por um regime de precariedade, que assinala uma proposição plural e corpórea para o direito da mulher aparecer (BUTLER, 2018). Portanto, os formatos de assembleia, dos grupos de mulheres articulados pela campanha, mobilizam ações e resistências pelo viés do conjunto e torna a posição de ativamente precários para a consolidação de uma base ativamente resistente (BUTLER, 2018).

Nessa direção, Butler (2018) nos ajuda a pensar, ao considerar os movimentos, como os dessa campanha, importantes pela produção de uma

8 Não tem a mesma tradição de ocupar as ruas como a Argentina e demais países da América Latina. 


\section{Palavras (não) Conclusivas}

Da necessidade de articular as dimensões - corpos, mulheres, ocupação de espaços públicos, reivindicações por respeito, não violência aos corpos - nasce este artigo que, por ora, tem a necessidade de fechar ou concluir suas discussões, mas, ao mesmo tempo, mostra que ainda tem muito a ser discutido. Temáticas como essas ainda precisam percorrer outros espaços, ocupar outras ruas, para serem dadas por exauridas.

Os meios de comunicação noticiam cada vez mais corpos violentados, alvos tanto de assédios, como violações físicas, quanto de ordens simbólicas, perpetrados pelos discursos masculinistas hegemônicos. O que faz com que os próprios corpos se posicionem, entrem em batalha, assumam essas campanhas contra as posições que constroem os corpos como violáveis. Corpos que 


\section{Corpos de Mulheres}

buscam (re)existir socialmente, buscam deslocar determinadas concepções hegemônicas de gênero submisso ao corpo do Outro.

Ainda que a passos curtos, esses grupos de mulheres brasileiras que se movimentam por meio da campanha Não é Não reivindicam o direito de respeito sobre seus corpos nos espaços públicos. Em um contexto social como o brasileiro, em que a cada hora mais de 500 mulheres são vítimas de agressão física (VELASCO; CAESAR; REIS, 2019), é praticamente impossível para os ativismos feministas absterem-se de abordar esse assunto.

Essa campanha é uma resposta contra-hegemônica. Entendemos como um espaço de fala de um grupo de mulheres que foi historicamente silenciado. Há em curso uma nova face de um espaço público sendo territorializado, compreendido entre as redes e as ruas, pelas mulheres. A campanha mostra-se como um dispositivo discursivo que tem como base respostas às precariedades de seus corpos, pela via da interatividade de grupos, em uma cultura participativa para apontar as especificidades de suas vivências e das violências que sofrem, ao mesmo tempo que possibilita a construção de uma inteligência coletiva entre as mulheres.

Ser reconhecida como um corpo de mulher no território brasileiro implica estar situada em um lócus de precariedade (BUTLER, 2018), passível de ser submetido a atos de violência que se intensificam pela lógica masculinista. $\mathrm{Na}$ campanha, os corpos passam a ser compreendidos como um objeto político ligado à ordem da linguagem, em busca de outras significações.

Quando dizemos Não é Não, ou seja, meu corpo não é um objeto, o alvo dos discursos são todos e de modo particular os homens. É uma campanha que conscientiza os homens brasileiros, pois boa parte deles ainda precisa modificar a forma com que enxergam e se relacionam com os corpos das mulheres. Essas campanhas que aliam redes e ruas têm se mostrado cada vez mais indispensáveis, seja na organização de assembleias públicas, nas trocas de conhecimentos ou no suporte educativo em relação às violências.

Outro ponto relevante, instigador e até fonte de esperança, é a crença de que muitas meninas e meninos que hoje estão se formando já nascem inseridos em outra cultura, o que cria condições de possibilidades para serem atingidos pelo discurso da equidade entre os gêneros desde muito cedo, quem sabe até proporcionando um contradiscurso imediato à socialização dessas crianças.

Para finalizar, escrevemos em nome das mulheres das gerações passadas; das que lutam e se organizam em campanhas como essa, pela legitimação de sua existência no presente sem violência aos corpos; e de todas aquelas que ainda virão, na esperança de que nossos corpos nunca mais sejam objetos nas mãos de homens que deixam neles marcas de violências. Enfim, continuamos lutando - por nós mesmas, mas também pelas novas gerações de mulheres, na esperança de que consigam, de fato, reafirmar que a Maria não é menor que o José.

\section{Referências}

BABO, Maria Augusta. Práticas de vida contemporânea na cidade. In: CABRERA, Ana; SANTOS, Clara Almeida; FIGUEIRAS, Rita (ed.). Media: poder, representação e epistemologias. Coimbra: Imprensa da Universidade 
Não é Não! Entre Redes e Ruas: Conflitualidade entre Cultura da Violência e

Corpos de Mulheres

de Coimbra, 2018, p. $201-218$.

BUTLER, Judith. Corpos em aliança e a política das ruas: notas para uma teoria performativa de assembleia. Trad. Fernanda Siqueira Miguens. Rio de Janeiro: Civilização Brasileira, 2018.

BUTLER, Judith. Quadros de guerra: quando a vida é passível de luto? Trad. Sérgio Lamarão e Arnaldo Marques da Cunha. 1. ed. Rio de Janeiro: Civilização Brasileira, 2015.

BUTLER, Judith; ATHANASIOU, Athena. Dispossession: the performative in the political. Cambridge: Polity, 2013.

COURTINE, Jean-Jacques. Os deslizamentos do espetáculo político. In: GREGOLIN, Maria do Rosário (org.). Discurso e mídia - a cultura do espetáculo. São Carlos: Editora Claraluz, 2003. p. 21-34.

DI FELICE, Massimo. Ser redes: o formismo digital dos movimentos netativistas. Revista Matrizes, n. 2, p. 49 - 71, 2013.

FOUCAULT, Michel. A ordem do discurso. São Paulo: Loyola, 2013.

FOUCAULT, Michel. As palavras e as coisas: uma arqueologia das ciências humanas. 8. ed. São Paulo: Martins Fontes, 1999.

GOMES, Thais Candido Stutz. Aprisionamento(s) de mulheres: a domesticação dos corpos no sistema prisional feminino. In: SÁ, Priscilla Placha (org.). Dossiê: as mulheres e o sistema penal. Curitiba: OABPR, 2015.

GRIFFIN, Susan. Woman and nature: the roaring inside her. New York: Harper and Row, 1978.

HELDMAN, Caroline. Sexual Objectification. Part 1: What is it? Dr. Caroline

Heldman, [online], 2 jul. 2012. Disponível em: $<$ https://drcarolineheldman.com/2012/07/02/sexual-objectification-part-1what-isit/\#: :text=If $\% 20$ objectification $\% 20$ is $\% 20$ the $\% 20$ process, that $\% 20$ serves $\% 20$ a nother $\% 27 \mathrm{~s} \% 20$ sexual\%20pleasure $>$. Acesso em: 20 agosto 2020.

HOLANDA, Sergio Buarque de. Raízes do Brasil. 4. ed. Brasília: Universidade de Brasília, 1963. (Biblioteca Básica Brasileira, 10).

HOOKS, Bell. Ensinando a transgredir: a educação como a prática da liberdade. São Paulo: Martins Fontes, 2013.

LOUREIRO, Carolina Piazzarollo. Corpo, beleza e auto-objetificação feminina. 2014. Dissertação (Mestrado em Psicologia), Programa de PósGraduação em Psicologia, Universidade Federal do Espírito Santo, Vitória, 
Não é Não! Entre Redes e Ruas: Conflitualidade entre Cultura da Violência e

Corpos de Mulheres

Espírito Santo.

MACEDO, Eunice. School rankings on the other hand... possibilities of young adult citizenship in the tension of educational and social change. 2012. Tese (Doutorado em Psicologia), Programa de Pós-Graduação em Psicologia, Faculdade de Psicologia e de Ciências da Educação, Universidade do Porto, Porto, Portugal.

NÃO É NÃO. Campanha Não é não. Instagram. 11 mar. 2020. Disponível em: <https://www.instagram.com/p/B9mRF8WpV1r/>. Acesso em: 15 agosto 2020.

NÃO É NÃO. Minas Gerais. Instagram. 20 mar. 2019b. Disponível em: $<$ https://www.instagram.com/p/BvP9JiWJTGC/>. Acesso em: 15 agosto 2020.

NÃO É NÃO. Não vendemos tatuagens. Instagram. 22 fev. 2019a. Disponível em: <https://www.instagram.com/p/BuL7HumlBW-/>. Acesso em: 15 agosto 2020.

RIBEIRO, Djamila. Vênus de Hotentote em qualquer lugar: a exotização da mulher negra. Blogueiras Negras, [online], 23 dez. 2013. Disponível em: $<\mathrm{http}$ ://blogueirasnegras.org/venus-hotentote-lugar-exotizacao-mulher-negra/ $>$. Acesso em: 15 agosto 2020.

SANTOS, Milton. A natureza do espaço: técnica e tempo. Razão e emoção. São Paulo: Hucitec, 1997.

SARDENBERG, Cecilia. Da violência simbólica de gênero à violência sexual contra mulheres: a lei antibaixaria e o caso da banda New Hit. In: CASTRO, Amanda Motta; MACHADO, Rita de Cássia. Estudos feministas - mulheres e educação popular. Vol. 2. São Paulo: Liber Ars, 2018, p. 135 - 156.

VALENZUELA, Sebástian. Analisando o uso de redes sociais para o comportamento de protesto: o papel da informação, da expressão de opiniões. Revista ComPolítica, v. 4, n. 1, p. 13 - 52, 2014.

VELASCO, Clara; CAESAR, Gabriela; REIS, Thiago. Mesmo com queda recorde de mortes de mulheres, Brasil tem alta no número de feminicídios em 2019. Portal G1, 5 mar. 2020. Disponível em: <https://g1.globo.com/monitorda-violencia/noticia/2020/03/05/mesmo-com-queda-recorde-de-mortes-demulheres-brasil-tem-alta-no-numero-de-feminicidios-em-2019.ghtml>. Acesso em: 15 agosto 2020.

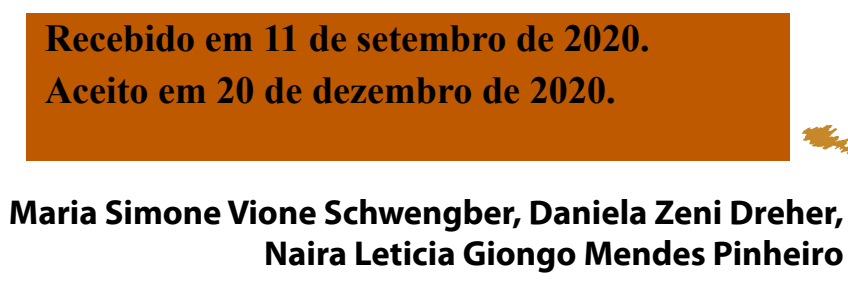

Revista Latino-americana de Geografia e Gênero, Ponta Grossa, v. 11, n. 2, p. 130 - 145, jul. / dez. 2020. 